\title{
Resistance to water deficit during the formation of sugarcane seedlings mediated by interaction with Bacillus sp.
}

\section{Resistência ao déficit hídrico na formação de mudas de cana-de-açúcar mediada pela interação com Bacillus sp.}

\author{
Michelli de Souza dos Santos ${ }^{1 *}$; Raissa Sylvestrin Stancatte ${ }^{2}$; Thiago Costa Ferreira ${ }^{3}$; \\ Dalton Vinicio Dorighello3; Ricardo Antônio Almeida Pazianotto4; Itamar Soares de Melo5; \\ André May ${ }^{5}$; Nilza Patrícia Ramos ${ }^{5}$ \\ ${ }^{1}$ Corresponding author. Bolsista de Pós-Doutorado, CAPES, Embrapa Meio Ambiente. SP 340, km 127,5, Bairro Tanquinho \\ Velho, CEP: 13820-000, Jaguariúna, SP, Brasil. michellisantos30@hotmail.com \\ ${ }^{2}$ Engenheira Ambiental e Sanitária, PUCC, Campinas-SP. ra.sstancatte@gmail.com \\ ${ }^{3}$ Doutorando em Proteção de Plantas, UNESP/FCA. ferreira_uepb@hotmail.com; dalton.agro@gmail.com \\ ${ }^{4}$ Analista Embrapa Meio Ambiente. ricardo.pazianotto@embrapa.br \\ ${ }^{5}$ Pesquisadores da Embrapa Meio Ambiente. Itamar.melo@embrapa.br; andre.may@embrapa.br; nilza.ramos@embrapa.br
}

Recebido em: 13-03-2017; Aceito em: 31-07-2017

\begin{abstract}
Sugarcane is a crop of great global importance, but its production can be greatly affected by water stress normally occurring in growing areas. Currently, several solutions have been proposed to minimize such effects, among them the use of microorganisms that improve the resistance of plants to water stress. The objective of this study was to evaluate the induction of resistance of sugarcane plants to water stress using Bacillus $\mathrm{sp}$. For this, an experiment was performed in controlled greenhouse conditions using billets provided with twenty different varieties of sugarcane, treated or not with Bacillus sp. isolates, with 5 replications. The plants were grown for 45 days and, after this period, the following variables were analyzed: dry mass (from top, root and whole plant) and C, $\mathrm{N}$ and $\mathrm{C} / \mathrm{N}$ contents. Analysis of variance, mean tests (Scott-Knott and Tukey, $\mathrm{p} \leq 0.05$ ) and a hierarchical analysis was performed by cluster analysis according to the UPGMA method (Unweighted Pair Group Method with Arithmetic Mean). The analyses were performed using the software R. The isolate of Bacillus sp. promoted resistance to drought for different varieties of sugarcane, and may be an alternative to mitigate the effects of water stress on some sugarcane varieties.
\end{abstract}

Additional keywords: drought; microorganism; varieties.

\section{Resumo}

A cana-de-açúcar é uma cultura de grande importância mundial, porém sua produção pode ser altamente prejudicada pelo estresse hídrico que normalmente ocorre nas áreas de cultivo. Atualmente, tem-se buscado diversas soluções para minimizar tais efeitos, dentre essas a utilização de microrganismos que melhorem a resistência das plantas ao estresse hídrico. Sendo assim, o objetivo deste trabalho foi avaliar a indução de resistência de plantas de cana-de-açúcar ao estresse hídrico por meio da utilização de Bacillus sp. Para isto, conduziu-se um experimento em condições controladas de casa de vegetação, com a utilização de rebolos providos de vinte diferentes variedades de cana-de-açúcar, tratados ou não com o isolado de Bacillus sp., com 5 repetições. Estas plantas foram cultivadas por 45 dias e, após esse período, foram analisadas as seguintes variáveis: massa seca (parte aérea, radicular e total) e teores $\mathrm{C}, \mathrm{N}$, e $\mathrm{C} / \mathrm{N}$. Foram realizados a análise de variância, os testes de média (Scott-Knott e Tukey, $p \leq 0,05$ ) e também uma análise hierárquica, por meio de uma análise de agrupamento, de acordo com o método UPGMA (Unweighted Pair Group Method with Arithmetic Mean). As análises foram realizadas com o uso do software $\mathrm{R}$. $\mathrm{O}$ isolado de Bacillus $\mathrm{sp}$. promoveu resistência à seca para diferentes variedades de cana-de-açúcar, podendo assim ser uma alternativa para atenuar os efeitos do estresse hídrico em algumas variedades de cana.

Palavras-chave adicionais: microrganismo; seca; variedades.

\section{Introduction}

The scenario of climate change on our planet, especially extreme events such as reduced rainfalls, makes food production increasingly challenging
(Wallace, 2000; IPCC, 2014). There is a steady increase in the demand for food production, which, in turn, increasingly drives agriculture to marginal areas where, in many cases, water deficit is constant (Foley et al., 2011). 
Water deficit causes several problems to plants because water is essential for biochemical and physiological processes that allow development and growth, limiting the normal agricultural production in diverse cultures, among them sugarcane (Sacharum spp.) (Taiz \& Zeiger, 2004; Lisar et al., 2012; Fang \& Xiong, 2015). This crop is grown in some parts of the world for the production of alcohol and sugar. Brazil has been reported as the world's largest producer of sugarcane, accounting for more than half of the sugar consumed in the world, with an estimated production of 47.34 million tons of sugar in the 2018-2019 crop (MAPA, 2016).

Modern varieties of sugarcane, even with advanced genetic improvement, have not achieved a good productivity when there is water restriction polygene, and therefore difficulty to be transmitted to new varieties (Barbosa, 2001; Reis et al., 2014; Kumar et al., 2014; Phan et al., 2016).

In this aspect, the use of diverse tools for the conviviality of plants cultivated commercially with water deficit has been studied, among them microorganisms. Studies show the viability of this biological tool in several agricultural crops, such as Helianthus annuus (Santos et al., 2014), Zea mays (Kavamura et al., 2013, Amada et al., 2015) and sugarcane (Schultz et al., 2012).

Among the most promising microbial genera to confer plants with resistance to drought, we can mention Bacillus. They are cosmopolitan microorganisms that can be found in varied and extreme environments, colonizing and promoting innumerable beneficial processes to plants (Zhang et al., 2014; Qin et al., 2015). For example, biological control, as presented by Araújo et al. (2002): isolates of $B$. subtilis generate toxic metabolites that compromise the movement of nematodes, inhibit the hatching of juveniles and still impair the action of root penetration of soybean plants. The genus Bacillus may also increase the availability of plant nutrients, such as phosphorus and nitrogen, in plants inoculated with rhizobacteria in seeds (Araújo, 2008). According to Vardharajula et al. (2011), the genus Bacillus, plant growth promoters, promotes induction of drought tolerance in corn plants.

Thus, this study aims to verify the induction of resistance to water deficit by seedlings of different sugarcane varieties inoculated with Bacillus sp.

\section{Material and methods}

The experiment was conducted in the city of Jaguariúna, SP (altitude $584 \mathrm{~m}, 2^{\circ} 42^{\prime 20 "} \mathrm{~S}$ and 46-59'09" W), in the experimental area of the Embrapa Environment during 2014, in a greenhouse with moisture and temperature control.

The planting was carried out on a soil from the same locatity. It is classified as a dystrophic Red-Yellow Latosol with a clayey texture. The physical-chemical characteristics of this soil, at the $0-20 \mathrm{~cm}$ layer, are $77 \mathrm{~g} \mathrm{~kg}^{-1}$ of clay, $P=24.2 \mathrm{mg} \mathrm{dm}^{-3}$, $\mathrm{K}^{+}=3.6 \mathrm{mmol} \mathrm{dm}^{-3}, \mathrm{Ca}_{2}{ }^{+}=45.6 \mathrm{mmolc} \mathrm{dm}^{-3}, \mathrm{Mg}+=$ $=22.8 \mathrm{mmolc} \mathrm{dm}-3$, and organic matter $==38.6 \mathrm{~g} \mathrm{~kg}^{-1}$, $\mathrm{pH}(\mathrm{H} 2 \mathrm{O})=5.1$.

The microorganism tested in this study was isolated from bacteria associated with cactus from the Brazilian semi-arid region, a bacterium of the genus Bacillus (Kavamura et al., 2013). The isolate is deposited at the collection of microorganisms of the Laboratory of Environmental Microbiology (LMA) of Embrapa Environment.

The experiment was completely randomized in a $2 \times 20$ factorial design with five replications: with and without the addition of Bacillus sp. isolates and 20 commercial varieties of sugarcane (Table 1).

Table 1 - Commercial varieties of sugarcane used in the experiment.

\begin{tabular}{clll}
\hline IAC & RIDESA & CTC \\
\hline IAC 3396 & RB 867515 & CTC 02 & CTC 20 \\
IAC 1099 & RB 72454 & CTC 04 & CTC 25 \\
IAC 5094 & RB 935744 & CTC 09 & CTC 9001 \\
IAC 5000 & RB 825211 & CTC 14 & CTC 9002 \\
& RB 855156 & CTC 15 & CTC 9003 \\
\hline
\end{tabular}

Bacteria were cultured in Petri dishes containing solidified yeast extract (GY) and kept in a BOD growth chamber at $25^{\circ} \mathrm{C}$ for 24 hours. Bacteria colonies were transferred to a liquid GY culture medium and incubated for 72 hours at $25^{\circ} \mathrm{C}$ in an orbital shaker at 5,488 $\times \mathrm{g}$. After this period, the material was centrifuged at $25{ }^{\circ} \mathrm{C}$ and $7,000 \mathrm{rpm}$ for $15 \mathrm{~min}$ for the formation of pallets, and cell concentration was adjusted in a spectrophotometer to obtain $10^{8} \mathrm{CFU} \mathrm{mL}^{-1}$ of Bacillus sp.
Sugarcane seedlings were inoculated with a suspension of Bacillus sp. by applying a bacterial solution over them. The application during the period of seedling formation occurred on the day of planting of buds ( 0 days) and 30 days after planting ( 30 days). After 30 days, the plants were inoculated weekly until transplanting to a definitive vessel. The seedlings were formed in tubes containing a substrate based on carbonized Pinus husk from the billets, containing one sugarcane bud per tube, according to the method of 
multiplication of pre-budded seedlings (Landell et al., 2012). The plants were kept without irrigation until reaching the wilting point for a period of 24 days, after which irrigation was performed up to $70 \%$ of field capacity, and the test was monitored for another 20 days.

At 45 days after the transplantation of seedlings to pots, the plants were removed, and shoots were separated from roots. Shoot dry matter (SDM), root dry matter (RDM) and total dry matter (TDM) were determined after drying the plant material in a forcedair ventilation oven at $65{ }^{\circ} \mathrm{C}$ until constant mass. Leaf samples and culms of sugarcane seedlings were also used for the determination of total carbon and nitrogen contents (\%) by dry combustion in a $\mathrm{C}$ and $\mathrm{N}$ elemental analyzer (TruSpec CN LECO ${ }^{\circledR}$ ).

Analysis of variance (ANOVA) and Scott-Knott mean tests $(p \leq 0.05)$ were used to evaluate the means obtained in the different treatments for the variables SDM, RDM, TDM, $N$ and $C / N$. The variable $C$ was evaluated by Tukey test $(p \leq 0.05)$. Statistical analyses were performed using the software R. To guarantee assumptions of homogeneity and normality, the variables RDM and TDM were transformed by square root, the variable $\mathrm{C} / \mathrm{N}$ was transformed by logarithm, and the $C$ variable was transformed by its square within a generalized model with heteroscedasticity between varieties ( $R$, Core Team, 2016).

We also performed a hierarchical analysis of data obtained for all studied variables considering data without transformation by cluster analysis according to UPGMA, generating a dendrogram considering the Euclidean distance in the matrix of dissimilarity for all variables. For such analysis, the software $R$ ( $R$ Core Team, 2016) was used.

\section{Results}

By the analysis of variance (ANOVA) of the results obtained in this study it was possible to observe that the following variables showed a significant interaction among the factors treatments and varieties: root dry matter (RDM), total dry matter (TDM) $(p<0.000)$, shoot dry matter (SDM) $(p<0.001), C / N$ ratio $(p<0.000)$ and $C$ content $(p<0.004)$. The nitrogen variable $(\mathrm{N})$ presented a significant main effect only for the factor variety $(p<0.000)$. There were differences reported by mean tests in relation to the results obtained for the interaction between the factors analyzed, except for some varieties (Table 4).

Regarding the variable SDM, the results of interaction among factors presented statistical differences between them. The most expressive results were observed with the presence and absence of the bacterial isolate, respectively, for the varieties RB 855156 (5.3569 g plant $\left.^{-1}\right)$ and IAC 5000 (4.799 g plant $^{1}$ ) (Table 2). The varieties CTC 20, IAC 3396, RB 855156 and RB 925211 presented the highest values for SDM when subjected to exposure to bacteria in relation to the control with water. CTC 9003 was the only one that presented the highest significant increase in the value of aerial part in the absence of bacteria.

According to the results observed for the variable RDM, it can be understood that, in the presence of the isolate, the variety RB 855156 (1.4074 $\mathrm{g} \mathrm{plant}^{-1}$ ) presented a better result; in the absence of the isolate, the variety IAC 1099 stood out (1.3407 g plant $^{-1}$ ) (Table 2). There was a greater increase in roots for the varieties CTC 15, CTC 9001 and RB 855156 in the presence of bacteria. However, without the presence of the isolate, some varieties presented high root dry matter values, especially the variety IAC 1099 .

The best results were observed for TDM with the presence and absence of the tested microorganism, respectively, for the varieties RB 855156 (2.8656 g plant ${ }^{-1}$ ) and CTC 5000 (2.58 g plant $\left.^{-1}\right)$ (Table 2). In the presence of bacteria, there was an increase in the total dry matter of CTC 17, CTC 20, CTC 9003, RB 855156 and RB 925211, while the varieties IAC 1099 and IAC 3396 presented a decrease in total dry matter with the application of bacteria.

The $\mathrm{C} / \mathrm{N}$ ratio presented the highest values, which were obtained in the presence and absence of the bacteria, respectively, for the varieties IAC 1099 (3.8025 g plant ${ }^{-1}$ ) and RB 925211 (3.7295 g plant $^{-1}$ ). There was an increase in the $\mathrm{C} / \mathrm{N}$ ratio in the varieties IAC 1099 and IAC 5000 when exposed to isolates of Bacillus sp., and a decrease in the varieties CTC 15 and RB 855156 (Table 3).

According to the results for the variable $\mathrm{C}$, it is possible to understand that, in the presence of the isolate, the variety IAC (2085.278 $\left.\mathrm{g} \mathrm{plant}^{-1}\right)$ presented the best results, and in its absence, the variety IAC 5000 stood out among the others $\left(1,163.426 \mathrm{~g} \mathrm{plant}^{-1}\right)$ (Table 3). Carbon contents increased in the presence of bacteria in the varieties IAC 1099 and IAC 5000 . The varieties CTC 14, RB 855156 and RB 925211 presented a decrease in the presence of the isolate.

For the $\mathrm{N}$ variable, it was verified just effect significant for variety factor. The varieties CTC 15 , CTC, CTC 20, CTC 9001, CTC 9002, CTC 9003, IAC 5094 and RB 7515 showed better results for the factor variety, and were statistically different from several other varieties (Table 4).

According to the analysis of the dendrogram (Figure 1), the results obtained in this study presented differences between them as for studied variables. The results obtained between the interaction of factors (treatments and varieties) were separated into two different groups. The first group included the following combinations: IAC 1099 in the presence in the isolate and CTC 14 and RB 925211 in its absence. The other combinations were described within a single group (Figure 1). 
Table 2 - Dry matter of the aerial part (SDM), dry matter of the roots (RDM), and dry matter of the whole plant (TDM) of sugarcane's varieties treated or not with Bacillus sp.

\begin{tabular}{lcccccc}
\hline \multirow{2}{*}{ Variety } & \multicolumn{2}{c}{ SDM } & \multicolumn{2}{c}{ RDM } & \multicolumn{2}{c}{ TDM } \\
& Bacillus & without & Bacillus & Without & Bacillus & without \\
\hline CTC 02 & $3.3669 \mathrm{cA}$ & $3.8339 \mathrm{bA}$ & $1.0601 \mathrm{cA}$ & $1.0592 \mathrm{cA}$ & $2.1414 \mathrm{dA}$ & $2.2426 \mathrm{cA}$ \\
CTC 04 & $2.6979 \mathrm{dA}$ & $2.5032 \mathrm{eA}$ & $1.1027 \mathrm{cA}$ & $1.0705 \mathrm{cA}$ & $2.0175 \mathrm{dA}$ & $1.9336 \mathrm{dA}$ \\
CTC 14 & $3.5535 \mathrm{cA}$ & $3.7092 \mathrm{cA}$ & $0.9086 \mathrm{dA}$ & $0.9186 \mathrm{dA}$ & $2.1144 \mathrm{dA}$ & $2.1748 \mathrm{cA}$ \\
CTC 15 & $4.2736 \mathrm{bA}$ & $4.3318 \mathrm{bA}$ & $1.0848 \mathrm{cA}$ & $0.9288 \mathrm{~dB}$ & $2.4089 \mathrm{cA}$ & $2.3335 \mathrm{bA}$ \\
CTC 17 & $3.8236 \mathrm{cA}$ & $3.3567 \mathrm{cA}$ & $1.0692 \mathrm{cA}$ & $0.9871 \mathrm{dA}$ & $2.2719 \mathrm{cA}$ & $2.1008 \mathrm{cB}$ \\
CTC 20 & $4.0534 \mathrm{bA}$ & $3.5309 \mathrm{cB}$ & $1.0560 \mathrm{cA}$ & $1.0349 \mathrm{cA}$ & $2.2995 \mathrm{cA}$ & $2.1557 \mathrm{cB}$ \\
CTC 25 & $4.2145 \mathrm{bA}$ & $4.0157 \mathrm{bA}$ & $1.1299 \mathrm{cA}$ & $1.1378 \mathrm{bA}$ & $2.3601 \mathrm{cA}$ & $2.3425 \mathrm{bA}$ \\
CTC 09 & $4.2835 \mathrm{bA}$ & $4.4437 \mathrm{aA}$ & $1.0290 \mathrm{dA}$ & $1.1051 \mathrm{cA}$ & $2.3229 \mathrm{cA}$ & $2.4343 \mathrm{bA}$ \\
CTC 9001 & $3.5907 \mathrm{cA}$ & $3.4394 \mathrm{cA}$ & $1.1397 \mathrm{cA}$ & $1.0006 \mathrm{cB}$ & $2.2888 \mathrm{cA}$ & $2.1671 \mathrm{cA}$ \\
CTC 9002 & $3.0408 \mathrm{dA}$ & $3.0906 \mathrm{dA}$ & $1.0141 \mathrm{dA}$ & $0.9726 \mathrm{dA}$ & $2.1435 \mathrm{dA}$ & $2.1017 \mathrm{cA}$ \\
CTC 9003 & $3.5154 \mathrm{cB}$ & $4.0927 \mathrm{bA}$ & $0.9724 \mathrm{dA}$ & $1.0185 \mathrm{cA}$ & $2.1376 \mathrm{~dB}$ & $2.3185 \mathrm{bA}$ \\
IAC 1099 & $4.0250 \mathrm{bA}$ & $4.2739 \mathrm{bA}$ & $1.1919 \mathrm{bA}$ & $1.3407 \mathrm{aB}$ & $2.3616 \mathrm{cB}$ & $2.5320 \mathrm{aA}$ \\
IAC 3396 & $5.2735 \mathrm{aA}$ & $4.5703 \mathrm{aB}$ & $1.3569 \mathrm{aA}$ & $1.3251 \mathrm{aA}$ & $2.7379 \mathrm{aA}$ & $2.5584 \mathrm{aB}$ \\
IAC 5000 & $4.4838 \mathrm{aA}$ & $4.7990 \mathrm{aA}$ & $1.2542 \mathrm{bA}$ & $1.2189 \mathrm{bA}$ & $2.5322 \mathrm{bA}$ & $2.5800 \mathrm{aA}$ \\
IAC 5094 & $3.3857 \mathrm{cA}$ & $3.3790 \mathrm{cA}$ & $0.9934 \mathrm{dA}$ & $1.0323 \mathrm{cA}$ & $2.0922 \mathrm{dA}$ & $2.1302 \mathrm{cA}$ \\
RB 72454 & $3.0911 \mathrm{dA}$ & $3.1294 \mathrm{dA}$ & $0.9801 \mathrm{dA}$ & $0.9125 \mathrm{dA}$ & $2.0244 \mathrm{dA}$ & $1.9889 \mathrm{dA}$ \\
RB 7515 & $3.8471 \mathrm{cA}$ & $3.6835 \mathrm{cA}$ & $1.1179 \mathrm{cA}$ & $1.1476 \mathrm{bA}$ & $2.2660 \mathrm{cA}$ & $2.2529 \mathrm{cA}$ \\
RB 855156 & $5.3569 \mathrm{aA}$ & $4.5389 \mathrm{aB}$ & $1.4074 \mathrm{aA}$ & $0.9320 \mathrm{~dB}$ & $2.8656 \mathrm{aA}$ & $2.4012 \mathrm{bB}$ \\
RB 925211 & $3.8513 \mathrm{cA}$ & $3.1012 \mathrm{~dB}$ & $0.9534 \mathrm{dA}$ & $0.9178 \mathrm{dA}$ & $2.2184 \mathrm{cA}$ & $1.9967 \mathrm{~dB}$ \\
RB 935744 & $4.5857 \mathrm{bA}$ & $4.2731 \mathrm{bA}$ & $1.0860 \mathrm{cA}$ & $1.0909 \mathrm{cA}$ & $2.4973 \mathrm{bA}$ & $2.4138 \mathrm{bA}$ \\
\hline
\end{tabular}

Means followed by different lowercase and capital letters in the column and line, respectively, differ significantly by Scott-Knott test ( $\mathrm{p} \leq 0.05)$.

Table 3 - Carbon-nitrogen proportion $(\mathrm{C} / \mathrm{N})$ and carbon content $(\mathrm{C})$ of sugarcane's varieties seedlings treated or not with Bacillus sp.

\begin{tabular}{|c|c|c|c|c|}
\hline \multirow[b]{2}{*}{ Variety } & \multicolumn{2}{|c|}{$\mathrm{C} / \mathrm{N}$} & \multicolumn{2}{|c|}{$\mathrm{C}^{1}$} \\
\hline & Bacillus & without & Bacillus & without \\
\hline CTC 02 & $3.5181 \mathrm{bA}$ & $3.6042 \mathrm{bA}$ & $1818.38 \mathrm{bcdA}$ & 1848.350 cdef $A$ \\
\hline CTC 04 & $3.5116 \mathrm{bA}$ & $3.5355 \mathrm{bA}$ & $1763.374 \mathrm{bcdA}$ & $1771.520 \mathrm{cdeA}$ \\
\hline CTC 14 & 3.5065 bB & $3.6574 \mathrm{aA}$ & $1858.190 \mathrm{~dB}$ & 1895.910 efA \\
\hline СТС 15 & $3.5283 \mathrm{bA}$ & $3.4927 \mathrm{cA}$ & $1791.612 \mathrm{~cd} A$ & $1780.586 \mathrm{cde} A$ \\
\hline СТС 17 & $3.5224 \mathrm{bA}$ & $3.5156 \mathrm{cA}$ & $1865.822 \mathrm{dA}$ & $1854.156 \operatorname{def} A$ \\
\hline СТС 20 & $3.4812 \mathrm{bA}$ & $3.3878 \mathrm{dA}$ & $1817.992 \mathrm{cdA}$ & $1625.242 \mathrm{abcd} A$ \\
\hline СТС 25 & $3.3808 \mathrm{bA}$ & $3.4133 \mathrm{dA}$ & $1269.386 \mathrm{aA}$ & $1384.860 \mathrm{abA}$ \\
\hline СТС 09 & $3.6340 \mathrm{bA}$ & $3.5651 \mathrm{bA}$ & $1992.154 \mathrm{dA}$ & 1821.574 bcdefA \\
\hline CTC 9001 & $3.4867 \mathrm{bA}$ & $3.4566 \mathrm{cA}$ & $1780.974 \mathrm{abcdA}$ & 1726.920 abcdefA \\
\hline CTC 9002 & $3.5380 \mathrm{bA}$ & $3.5531 \mathrm{bA}$ & $1973.972 \mathrm{dA}$ & 1837.670 cdefA \\
\hline CTC 9003 & $3.5785 \mathrm{bA}$ & $3.6073 \mathrm{bA}$ & $1970.906 \mathrm{dA}$ & $2160.628 \mathrm{fA}$ \\
\hline IAC 1099 & $3.8025 \mathrm{aA}$ & $3.5934 \mathrm{bB}$ & $2085.278 \mathrm{dA}$ & $1711.724 \mathrm{abcdefB}$ \\
\hline IAC 3396 & $3.5427 \mathrm{bA}$ & $3.5461 \mathrm{bA}$ & $1335.148 \mathrm{aA}$ & $1439.984 \mathrm{abcA}$ \\
\hline IAC 5000 & $3.4865 \mathrm{bA}$ & $3.3780 \mathrm{~dB}$ & $1289.198 \mathrm{abcA}$ & $1163.426 \mathrm{aB}$ \\
\hline IAC 5094 & $3.5537 \mathrm{bA}$ & $3.5161 \mathrm{cA}$ & $1900.998 \mathrm{dA}$ & 1965.632 ef $A$ \\
\hline RB 72454 & $3.5947 \mathrm{bA}$ & $3.5786 \mathrm{bA}$ & $1834.514 \mathrm{dA}$ & $1855.506 \operatorname{def} A$ \\
\hline RB 7515 & $3.5660 \mathrm{bA}$ & $3.5001 \mathrm{cA}$ & $1865.354 \mathrm{dA}$ & $1867.456 \operatorname{def} A$ \\
\hline RB 855156 & 3.4825 bB & $3.6366 \mathrm{aA}$ & $1475.460 \mathrm{abcdB}$ & $1830.274 \mathrm{abcdef} A$ \\
\hline RB 925211 & 3.5466 bB & $3.7295 \mathrm{aA}$ & $1579.096 \mathrm{abcdB}$ & $1777.652 \mathrm{abcdef} A$ \\
\hline RB 935744 & $3.5191 \mathrm{bA}$ & $3.4978 \mathrm{bA}$ & $1479.270 \mathrm{abA}$ & $1765.914 \mathrm{cdeA}$ \\
\hline
\end{tabular}

Means followed by different lowercase and capital letters in the column and line, respectively, differ significantly by Scott-Knott test $(p \leq 0.05)$. 
Table $4-\mathrm{N}$ content in different varieties of sugarcane seedlings.

\begin{tabular}{lcrc}
\hline Variety & $\mathrm{N}\left(\mathrm{g} \mathrm{kg}^{-1}\right)$ & Variety & $\mathrm{N}\left(\mathrm{g} \mathrm{kg}^{-1}\right)$ \\
\hline CTC 02 & $12.2 \mathrm{~b}$ & CTC 9003 & $12.5 \mathrm{a}$ \\
CTC 04 & $12.4 \mathrm{~b}$ & IAC 1099 & $10.8 \mathrm{~d}$ \\
CTC 14 & $12.1 \mathrm{~b}$ & IAC 3396 & $10.7 \mathrm{~d}$ \\
CTC 15 & $12.7 \mathrm{a}$ & IAC 5000 & $11.2 \mathrm{~cd}$ \\
CTC 17 & $12.8 \mathrm{a}$ & IAC 5094 & $12.8 \mathrm{a}$ \\
CTC 20 & $13.4 \mathrm{a}$ & RB 72454 & $11.9 \mathrm{~b}$ \\
CTC 25 & $12.2 \mathrm{~b}$ & RB 7515 & $12.7 \mathrm{a}$ \\
CTC 09 & $11.9 \mathrm{~b}$ & RB 855156 & $11.4 \mathrm{c}$ \\
CTC 9001 & $13.0 \mathrm{a}$ & RB 925211 & $17.5 \mathrm{C}$ \\
CTC 9002 & $12.6 \mathrm{a}$ & RB 935744 & $12.1 \mathrm{~b}$ \\
\hline
\end{tabular}

Means followed by different lowercase letters in the column differ significantly by Tukey test $(p \leq 0.05)$.

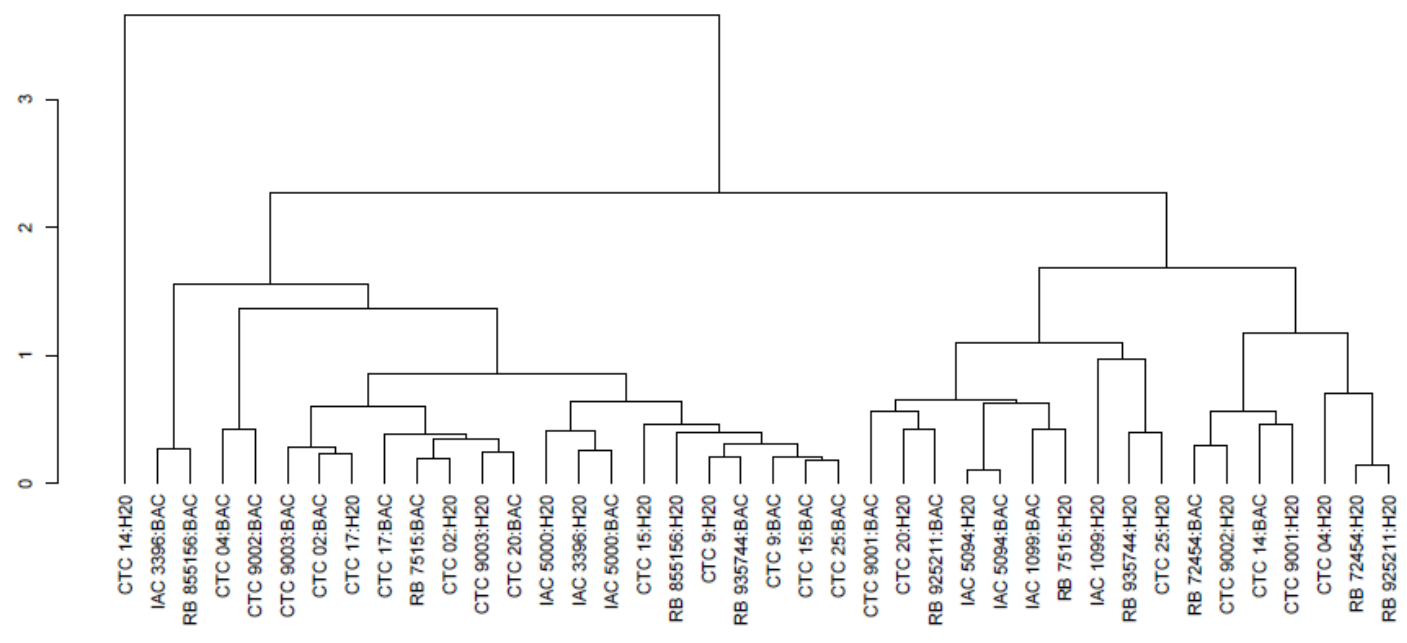

Figure 1 - Dendogram elaborated from the averages of the characteristics of sugarcane's varieties.

\section{Discussion}

The low availability of water to plants may limit their development. Thus, the use of microorganisms may provide a better resistance by plants to water stress, becoming a good alternative for the management of sugarcane crops. Morphological changes due to water deficit may be easy to verify in plants, such as decrease in height, leaf size and yield. However, evaluations may be more complex, such as increased root volume and decrease in fresh and dry matter of various parts of the plant (Torrecillas et al., 1996).

In general, among the 20 evaluated varieties, the one that presented the best behavior in face of water stress, when compared to treatments with the absence of bacteria for the majority of the variables evaluated, was the variety RB 855156 . In a study by Torres et al. (2012), this variety showed a reduction in stomatal conductance after the application of herbicides, indicating that, under stress situations, this variety may have a specific protection mechanism.

The increase in shoot dry matter (SDM) in the varieties CTC 20, IAC 3396, RB 855156 and RB 925211, in the presence of bacteria, can be due to a better relation of these varieties with the isolate applied, denoting a possible higher efficiency by plants in association with the isolate for the use of water for the production of dry matter. In a study conducted by Silveira et al. (2004), there was an increase in the growth of cucumber plants inoculated with isolates of Bacillus amyloliquefaciens and Enterobacter cloacae. According to Araújo \& Hungria (1999), the inoculation of soybean seeds with Bacillus increased the amount of nodules by $59 \%$ at the V3 stage, increased nodules occupation by Bradyrhizobium strains by $76 \%$ at R2, and increased grain yield by $24 \%$ when compared to the control without inoculation of Bacillus.

The presence of bacteria also provided an increase in root dry matter in some of the studied varieties (CTC 15, CTC 9001 and RB 855156). According to Govindarajan et al. (2006), there was an increase in sugarcane biomass $(20 \%)$ with the inoculation of Burkholderia spp. The authors Mirza et al. (2001), testing bacteria of the genus Enterobacter in sugarcane plants micropropagated in vitro, reported an increase in root dry matter. The highest increase in root growth may provide the plant with a greater nutrient uptake and consequently a greater resistance to abiotic fac- 
tors such as water deficit. The varieties CTC 17, CTC 20, CTC 9003, RB 855156 and RB 925211 showed the highest plant total dry matter. According to studies conducted by Ashraf et al. (2011), rhizobacteria promote an increase in root and shoot dry matter. According to Cohen et al. (2008), rhizobacteria can modify the hormonal signaling of plants, changing stomatal opening, improving water use and promoting a greater production of total dry matter.

Other crops were already tested as for the use of bacteria to improve plant behavior in order to obtain better yields under conditions adverse to plant development. For example, Nowak et al. (1999) studied the effects of bacteria on potato transplanting. The authors verified that plants inoculated with bacteria behaved better in years with low rainfalls, but this did not occur in years with severe drought or heavy rains. Productivity was higher for plants inoculated with bacteria. The authors also found a significant interaction between potato varieties and bacteria regarding plant growth. Therefore, bacteria have to be tested in different varieties, because the relation can be changed and the isolate may not present a positive effect on the plant.

Thus, the use of microorganisms to reduce the deleterious effects of water stress becomes a viable alternative for management. In a study conducted by Beltrano \& Ronco (2008), which verified the effects of Glomus claroideum on tolerance to water deficit by wheat plants, the authors found that root colonization by $G$. claroideum would probably be an appropriate management measure aiming to reduce the negative impacts of water stress on wheat. Porcel \& Ruiz-Rozano (2004) also reported a positive effect of mycorrhizal fungi on water stress in soybeans.

The increase in shoot and root dry matter of some sugarcane varieties inoculated with bacteria are tolerance responses of the bacteria to water deficit. According to McCree \& Fernández (1989), the best responses to water deficiency are reduction in leaf area, closure of stomata, acceleration of senescence and abscission of leaves because water is indispensable to cell growth and a fundamental component for the conservation of turgescence. According to a study by Ball et al. (1994), the greatest development of roots occurred at soil layers where water was more available, and the propagation of roots in field was more compromised by water deficit than by leaf development.

In addition to the effects on growth and productivity, plants subjected to water stress may decrease the production of enzymes and nutrients (Pereira et al., 2015).

As can be seen in Table 3 and Figure 1, which show the analysis of the variable $\mathrm{C} / \mathrm{N}$, we observed that, in general, there were no discrepant results in the absence and presence of bacteria. Such results can be explained by the fact that, on average, the $\mathrm{C} / \mathrm{N}$ ratio in straws of sugarcane, according to Ramos et al. (2016), is a variable that can be influenced by many environ- mental factors, but that in general organic materials have very marked characteristics in relation to this variable since they are adjusted by the structure and the type of the organic materials constituent of vegetal tissues. Thus, the results show that in the presence of bacteria, there is an average increase of $0.02 \%$ in the variable $\mathrm{C} / \mathrm{N}$. We also found an increase of $0.96 \%$ in the presence of the microorganism for the variable $\mathrm{C}$ (Tables 3 and 4).

It is known that the fraction of carbon in the $\mathrm{C} / \mathrm{N}$ ratio comprises organic fractions of different materials (Pitombo et al., 2015). The $C$ fraction of this ratio describes the amount of organic compounds in this relation, and thus a better absorption of nutrients and $\mathrm{CO}_{2}$ may increase or decrease the percentages of this element simply due to the production of more tissues by plants. The $\mathrm{N}$ fraction of the $\mathrm{C} / \mathrm{N}$ ratio plays an important role in the basic functions of plant physiology, being essential for almost all functions (Ramos et al., 2016).

In the three variables of this group of analyses (C/N ratio, $\mathrm{C}$ and $\mathrm{N}$ content), the variety IAC 5094 presented good results in the absence of the microorganism among the other varieties studied, a fact that can be evidenced by the rusticity of the variety against adversities and the likely low compatibility with the isolate studied (Tables 3 and 4).

It can be described that there is a profitable relation of the use of Bacillus sp. isolates. However, changes in this group of analyses ( $\mathrm{C} / \mathrm{N}$ ratio, $\mathrm{C}$ content and $\mathrm{N}$ content) were inexpressive between inoculated and non-inoculated plants. However small that increase may be with the use of isolates, it is satisfactory when taking into account productivity and gain for thousands of hectares of sugarcane.

\section{Conclusions}

Bacillus sp. isolates promoted an improvement in the variables evaluated for the sugarcane varieties CTC 20, IAC 3396, RB 855156 and RB 925211, promoting resistance to drought during the formation of seedlings.

\section{References}

Amada E, Azcon R, López-Castillo OM, Calvo-Polanco M, Ruiz-Lozano JM (2015) Autochthonous arbuscular mycorrhizal fungi and Bacillus thuringiensis from a degraded Mediterranean area can be used to improve physiological traits and performance of a plant of agronomic interest under drought conditions. Plant Physiology and Biochemistry 90:64-74.

Araújo FF, Hungria M (1999) Nodulação e rendimento de soja co-infectada com Bacillus subtilis e Bradyrhizobium japonicum / Bradyrhizobium elkanii. Pesquisa Agropecuária Brasileira 34:1633-1643.

Araújo FF, Silva JFV, Araújo ASF (2002) Influência de Bacillus subtilis na eclosão, orientação e infecção de Heterodera glycines em soja. Ciência Rural 32: 197--202. 
Araújo FF (2008) Inoculação de sementes com Bacillus subtilis, formulado com farinha de ostra e desenvolvimento de milho, soja e algodão. Ciência e Agrotecnologia 2:456-46.

Ashraf MA, Rasool M, Mirza MS (2011) Nitrogen fixation and indole acetic acid production potential of bacteria isolated from rhizosfere of sugarcane (Saccharum officinarum L.). Advances in Biological Research 5:348-355, 2011.

Ball RA, Oosterhuis DM, Mauromoustakos A (1994) Growth dynamics of the cotton plant during water-deficit stress. Agronomy Journal 86:788-795.

Barbosa MHP (2001) Study of genetic divergence in sugarcane varieties grown in Brazil using the parentage coefficient. International Sugar Journal 103(1231):294-295.

Beltrano J, Ronco MG (2008) Improved tolerance of wheat plants (Triticuma estivum L.) to drought stress and rewatering by the arbuscular mycorrhizal fungus Glomus claroideum: Effect on growth and cell membrane stability. Brazilian Journal Plant Physiology 20:29-37.

Cohen AC, Bottini R, Piccoli PN (2008) Azospirillum brasilense Sp245 produces ABA in chemically-defined culture medium and increases ABA content in Arabidopsis plants. Plant Growth Regulation 54:97-103.

Fang Y, Xiong L (2015) General mechanisms of drought response and their application in drought resistance improvement in plants. Cellular and Molecular Life Sciences 72:673-689.

Foley JA, Ramankutty N, Brauman KA, Cassidy ES, Gerber JS, Jonhston M, Mueller ND, O'Connell C, Ray DP, West PC, Balzer C, Bennett EM, Carpenter SR, Hill J, Monfreda C, Polasky S, Rockstrõm J, Sheehan J, Sheehan J, Siebert S, Tilman D, Zaks DP (2011) Solutions for a cultivated planet.. Nature 478(7369):337-42.

Govindarajan M, Balandreau J, Muthukumarasamy R, Revathi G, Lakshminarasimhan C (2006) Improved yield of micropropagated sugarcane following inoculation by endophytic Burkholderia vietnamiensis. Plant and Soil 280(1):239-252.

IPCC (2014) Summary for policymakers. In: IPCC. Climate Change 2014: impacts, adaptation, and vulnerability. Contribution of Working Group II to the Fifth Assessment Report of the Intergovernmental Panel on Climate Change. Cambridge, UK and New York, USA, Cambridge University Press. p.1-32.

Kavamura V, Santos SN, Silva Jlda, Parma MM, Avila LA, Visconti A, Zucchi TD, Taketani RG, Andreote FD, Melo ISde (2013) Screening of Brazilian cacti rhizobacteria for plant growth promotion under drought. Microbiological Research 168(4):183-191.
Kumar T, Uzma, Khan MR, Abbas Z, Ali GM (2014) Genetic Improvement of Sugarcane for Drought and Salinity Stress Tolerance Using Arabidopsis Vacuolar Pyrophosphatase (AVP1) Gene. Molecular Biotechnology 56(3):199-209.

Landell MGA, Campana MP, Figueiredo P (2012) Sistema de multiplicação de cana-de-açúcar com uso de mudas pré-brotadas (MPB), oriundas de gemas individualizadas. Campinas: Instituto Agronômico, IAC 109.

Lisar SYS, Motafakkerazad R, Hossain MM, Rahman, IMM (2012) Water stress in plants: causes, effects and responses. In Rahman IMdMofizur, Hasegawa H (eds.) Water Stress, Rijeka: Intech Europe, p. 3-15.

MAPA - Ministério da Agricultura, Pecuária e Abastecimento (2016) Disponível em: $<$ http://www.agricultura.gov.br/vegetal/culturas/canadeacucar>. Acesso em 14 jan. 2017.

Mccree KJ, Fernández CJ (1989) Simulation model for studyng physiological water stress responses of whole plants. Crop Science 29:353-360.

Mirza MS, Ahmad W, Latif F, Haurat J, Bally R, Normand P, Malik KA (2001) isolation, partial characterization, and effect of plant growth-promoting bacteria (PGPB) on micropropagated sugarcane in vitro. Plant and Soil 237:47-54.

Nowak J, Bensalim S, Smith C, Dunbar C, Asiedu SK, Madani A, Lazarovits G, Northcott DD, Sturz AV (1999) Behaviour of plant material issued from in vitro bacterization. Potato Research 42:505-519.

Pereira CCMS, Pedrosa EMR, Rolim MM, Cavalcante UMT, Monte Junior IP, Pereira Filho JV (2015) Initial development and chemical components of sugarcane under water stress associated with arbuscular mycorrhizal fungi. Revista Brasileira de Engenharia Agrícola e Ambiental 19:548-552.

Phan TT, Sun B, Niu JQ, Tan QL, Yang LT, Li YR (2016) Overexpression of sugarcane gene SoSnRK2.1 confers drought tolerance in transgenic tobacco. Plant Cell Reports 35:1891-19054.

Pitombo LM, Do Carmo JB, De Maria IC, De Andrade CA (2015) Carbon sequestration and greenhouse gases emissions in soil under sewage sludge residual effects. Scientia Agricola 72:147-156.

Porcel R, Ruiz-Lozano JM (2004) Arbuscularmycorrhizal influence on leaf water potential, solute accumulation, and oxidative stress in soybean plants subjected to drought stress. Journal of Experimental Botany 55:1743-1750.

Qin Y, Han Y, Shang Q, Li P (2015) Complete genome sequence of Bacillus amyloliquefaciens $\mathrm{L}-\mathrm{H} 15$, a plant growth promotion rhizobacteria isolated from cucumber seedling substrate. Journal of Biotechnology 200: 59-60. 
R Core Team. R (2016) A Language and Environment for Statistical Computing. Vienna, Austria: R Foundation for Statistical Computing.

Ramesh P (2000) Effect of different levels of drought during the formative phase on growth parameters and its relationship with dry matter accumulation in sugarcane. Journal of Agronony \& Crop Science 185:83-89.

Ramos NP, Yamaguchi CS, Pires AMM, Rossetto R, Possentti RA, Packer AP, Cabral OMR, Andrade CA (2016) Decomposição de palha de cana-de-açúcar recolhida em diferentes níveis após a colheita mecânica. Pesquisa Agropecuária Brasileira 51(9): 1492-1500.

Reis RR, da Cunha BA, Martins PK, Martins MT, Alekcevetch JC, Chalfun AJr, Andrade AC, Ribeiro AP, Qin F, Mizoi J, Yamaguchi-Shinozaki K, Nakashima K, Carvalho $J$ de $F$, de Sousa CA, Nepomuceno AL, Kobayashi AK, Molinari HB (2014) Induced overexpression of AtDREB2A CA improves drought tolerance in sugarcane. Plant Sciences 221-222:59-68.

Santos JF, Sacramento BL, Mota KNAB, Souza JT, Azevedo Neto, ADe (2014) Crescimento de girassol em função da inoculação de sementes com bactérias endofíticas. Pesquisa Agropecuária Tropical 44(2): $142-150$.

Schultz N, Morais RFde, Silva JAda, Baptista RB, Oliveira RP, Leite JM, Pereira W, Carneiro Junior, JdeB, Alves BJR, Baldani JI, Boddey RM, Urquiaga S, Reis V (2012) Avaliação agronômica de variedades de cana-de-açúcar inoculadas com bactérias diazotróficas e adubadas com nitrogênio. Pesquisa Agropecuaria Brasileira 47(2):261-268.
Silveira EB, Gomes AMA, Mariano RLR, Silva Neto EB (2004) Bacterização de sementes e desenvolvimento de mudas de pepino. Horticultura 22(2):217-221.

Taiz L, Zeiger E (2004) Fisiologia vegetal. Porto Alegre: Artmed, $719 \mathrm{p}$.

Torrecillas A, Alarcón JJ, Domingo R, Planes J, Sánchez-Blanco (1996) Strategies for drought resistance in leaves of two almond cultivars. Plant Science, 118(2):135-143.

Torres, LG, Ferreira EA, Rocha PRR, Faria AT, Gonçalves VA, Galon, L, Silva AF, Silva AA (2012) Alterações nas características fisiológicas de cultivares de cana-de-açúcar submetida à aplicação de herbicidas. Planta Daninha, 30(3), 581-587.

Vardharajula S, Zulfikar AS, Grover M, Reddy G, Bandi V. (2011) Drought-tolerant plant growth promoting Bacillus spp.: effect on growth, osmolytes, and antioxidant status of maize under drought stress. Journal of Plant Interactions 6:1-14.

Wallace JS (2000). Increasing agricultural water use efficiency to meet future food production. Agriculture, Ecosystms \& Environment 82:105-119.

Zhang R, Shen Q, Zhang N, Xu Z, Shao J (2014) Contribuition of indole-3-acetic acid in the plant growth promotion by the rhizospheric straim Bacillus amyloliquefaciens SQR9. Biology and Fertility of Soils 51:321-330. 